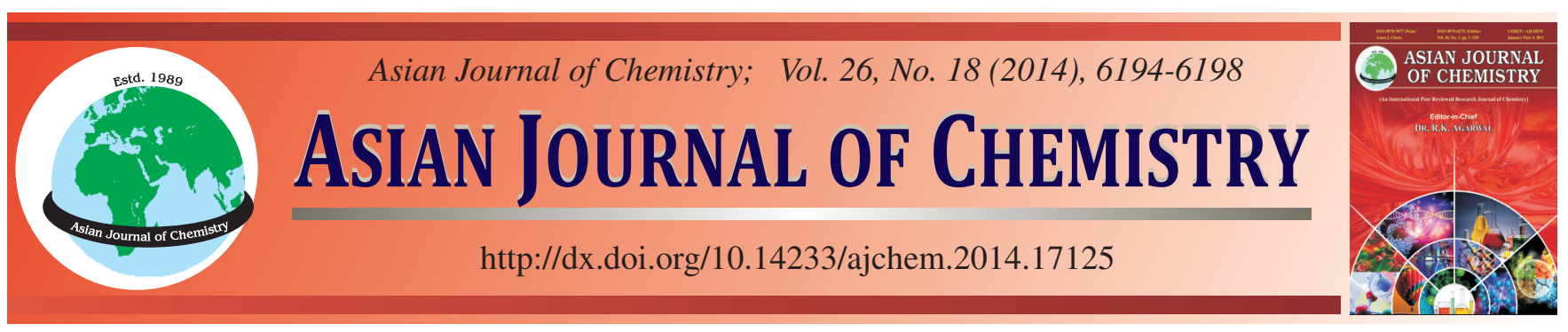

\title{
Phytochemical Screening of Plants Used in Folkloric Medicine: Effect of Extraction Method and Solvent
}

\section{Mazhar Abbas $^{1, *}$, Muhammad Shahid $^{1}$, Munir A. Sheikh $^{1}$ and Ghulam Muhammad ${ }^{2}$}

${ }^{1}$ Department of Chemistry and Biochemistry, University of Agriculture, Faisalabad-38040, Pakistan

${ }^{2}$ Department of Clinical Medicine and Surgery, University of Agriculture, Faisalabad-38040, Pakistan

*Corresponding author: E-mail: mazharabbas216@yahoo.com

Keywords: Medicinal plant, Extraction method, Extracting solvent, Phytochemical and FTIR analysis.

\section{INTRODUCTION}

The history of plants as high valuable source of medicines dates back to 4000 to 5000 B.C. The forerunners in using plants as medicinal source were Chinese and Indian. Authoritative and invaluable information and references regarding drug yielding plants have been extensively described by Dioscorides in his famous book 'De Materia Medica'. So, among all invaluable sources of drug yielding plants, nature is the most important source of medicine development ${ }^{1}$. Since immemorial time, researchers have proved that diagnosis, treatment and management of death causing diseases through plants cannot be accentuated. This feature of plants makes them most significant and safe source for diagnosis and treatment of human ailments ${ }^{2}$.

Until now, various active components have been extracted from medicinal plants and are utilized by pharmaceutical companies in the synthesis of allopathic medicines and then these are used against human and animal infections. More than 400,000 species of plants contain phyto components such as bioactive peptides, dyes, rubbers, flavonoids, gums resins, phyto hormones and bio pesticides have been reported. World Health Organization (WHO) reports show that about $80 \%$ health care requirements are dependent on plants particularly medicinal plants ${ }^{3}$.
Plant produces the primary and secondary metabolites responsible for their biological activities. Primary metabolites include those products which are important for growth and survival of plants ${ }^{4}$, whereas secondary metabolites make defensive system of plants such as alkaloids, terpenes and phenolic compounds etc which are biologically active $e^{5}$. More then 200 medicinal species having medicinal value have been studied in the region ${ }^{1,6}$. However, some of these species have become extinct due to more extraction from medicinal plants and over collection ${ }^{7}$. But in Pakistan, medicinal plants are facing threats for their survival due to over collection, lack of knowledge of threats of medicinal plants, heavy grazing and lack of knowledge of scientific work ${ }^{8}$. In this regard, new species of medicinal plant was considered in this study. The research was planned to screen and quantify the phyto-chemicals components from Ricinus communis, Croton tiglium and Datura innoxia medicinal plants.

\section{EXPERIMENTAL}

All the chemicals and reagents used were of analytical grade. The medicinal plants Ricinus communis, Croton tiglium and Datura innoxia collected from Botanical Garden, University of Agriculture Faisalabad, Pakistan. The classification of 
selected plant is given in Table-1. The plants were further identified and authenticated by the Taxonomist Dr. M. Hameed, Department of Botany, University of Agriculture Faisalabad, Pakistan.

\begin{tabular}{cccc}
\multicolumn{4}{c}{ TABLE-1 } \\
\multicolumn{4}{c}{ SCIENTIFIC AND COMMON NAME } \\
& OF SELECTED MEDICINAL PLANTS \\
\hline Sr. No & Scientific name & Local/common & Family name \\
\hline 1 & Ricinus communis & Arind & Euphorbiaceae \\
2 & Croton tiglium & Jamalghota & Euphorbiaceae \\
3 & Datura innoxia & Datura & Solanaceae \\
\hline
\end{tabular}

Extraction of plant material: For extraction, $25 \mu \mathrm{m}$ mesh size of plant dried material was used. For extraction absolute methanol was used. The extracts extracted with absolute methanol were further fractionated using $n$-hexane, chloroform, ethyl acetate and $n$-butanol ${ }^{9}$. After fractionation, samples were concentrated to dryness using rotary evaporator. The samples were stored in a refrigerator at $4{ }^{\circ} \mathrm{C}$ until used for further analysis. Other then solvent, different extraction method such as shaking, soxhlet and sonication used for extraction ${ }^{10,11}$.

Proximate analysis: The dried plants powder was analyzed for moisture content, crude proteins, crude fats, crude fibers and ash content by the following methods. The moisture, crude protein and crude fats and ash contents content were determined by using the method described by Ayuba et al. ${ }^{12}$, whereas crude fiber was determined precisely as reported by Pushpa et al. ${ }^{13}$. Total carbohydrates were calculated by difference method as, $\{$ total carbohydrates $=100-($ total moisture + total protein + total fat + total ash) $\}$. The total energy was calculated according to the method reported elsewhere ${ }^{14}$ using following relation, $\{$ energy $(\mathrm{Kcal})=4 \times(\mathrm{g}$ protein $+\mathrm{g}$ carbohydrate $)+$ $9 \times($ g lipid $)\}$.

Phytochemical qualitative and quantitative analysis: To test alkaloids, $2 \mathrm{~mL}$ of the extract and $0.2 \mathrm{~mL}$ of dilute hydrochloric acid were taken and $1 \mathrm{~mL}$ of Mayer's reagent was added. A yellowish buff precipitate indicated the presence of alkaloids ${ }^{14}$. For tannins, plant extract $(0.5 \mathrm{~g})$ was boiled in $10 \mathrm{~mL}$ of water for $5 \mathrm{~min}$, filtered and few drops of $0.1 \%$ ferric chloride was added ${ }^{15}$. For terpenoide, Salkowski's test was used. Briefly, chloroform ( $1 \mathrm{~mL}$ ) was added to $200 \mu \mathrm{L}$ of the extract along with few drop of concentrated sulfuric acid ${ }^{16}$. To test flavonoids, few drops of concentrated hydrochloride acid were added to a small amount of plant extract and noted the color of resultant solution ${ }^{17}$. The saponins, phlobatanins, steriods and cardiac glycosides were determined following reported methods ${ }^{15,16,18,19}$. For quantitative estimation of alkaloid, saponin and flavonoid was performed following methods reported elsewhere ${ }^{20-22}$.
Statistical analysis: The percentage yield, proximate components and phytochemicals were determined in triplicate and responses, thus obtained averaged and reported as mean $\pm \mathrm{SD}$.

\section{RESULTS AND DISCUSSION}

Percentage yield of plants extracts and fractions: The percentage yield (w/w) R. communis extract of whole plant and seeds extracted with methanol were $60.60 \mathrm{~g} / 100 \mathrm{~g}$ and $52.2 \mathrm{~g} / 100 \mathrm{~g}$, respectively. The fractions ( $n$-hexane, chloroform, ethyl acetate and $n$-butanol) showed percentage yield in the range $9.8-18.1 \mathrm{~g} / 100 \mathrm{~g}$ and $6.4-20.8 \mathrm{~g} / 100 \mathrm{~g}$ in whole plant and seeds of $R$. communis, respectively. The extraction of bioactive compounds from $D$. innoxia whole plant and seeds in methanol was $66.01 \mathrm{~g} / 100 \mathrm{~g}$ and $56 \mathrm{~g} / 100 \mathrm{~g}$, whereas fractions of whole plant showed 9.7-23.6 g/100g and 5.7-16.2 $\mathrm{g} / 100 \mathrm{~g}$ in seeds in different solvents. Overall, whole plant furnished better yields of bioactive compounds. C. tiglium yield was recorded to be $47 \mathrm{~g} / 100 \mathrm{~g}$ and $51 \mathrm{~g} / 100 \mathrm{~g}$ in whole plant and seeds extracted with methanol, respectively. The $C$. tiglium fractions showed the yield in the range of 3.7-19.6 g/100g and $6.5-18.1 \mathrm{~g} / 100 \mathrm{~g}$, respectively in whole plant and seed in different solvents $(n$-hexane $<$ chloroform $<$ ethyl acetate $<$ $n$-butanol). In case of fractionation, $n$-hexane extract of $D$. innoxia (whole plant) showed better yield, whereas minimum yield was observed in $n$-butanol fraction of $C$. tiglium whole plant (Table-2). Among solvents, methanol furnished better response regarding extraction of phytochemicals and similar trend has been reported previously for the extraction of phytochemical from plant material ${ }^{23,24}$. Zhao et al. $^{25}$ also revealed that solvent can affects the extraction of bioactive compounds from plant material.

Furthermore, the yield of medicinal plants extracted in methanol was also evaluated on the basis of extraction technique such as shaking, sonication and soxhlet methods. It was observed that shaking method showed best yield. Among plant parts (seed, stem, leaves, fruit and roots), seeds furnished better yield followed by leaves as compared to other parts. The percentage yield of seeds extracts was $60.72 \%$ in $R$. communis, $52.8 \%$ in D. innoxia and $27.09 \%$ in C. tiglium. Regarding plant parts, seeds, stems, leaves, fruits and roots of $R$. communis showed $60.72,6.5,39.4,21.5$ and $4.84 \%$ yields, respectively, whereas D. innoxia furnished 13.4, 13.9, 19.4, 15.5 and $21.5 \%$ yield and $C$. tiglium yields were 16.65, 8.4, 17.6, 14.45 and $6.4 \%$, respectively (Table- 3 ).

Proximate analysis: The results of proximate composition of medicinal plants under investigation are shown Table-4. The proximate analysis indicate that as usual in plant, there was a variation in crude protein content which ranged from

\begin{tabular}{|c|c|c|c|c|c|c|c|c|c|c|}
\hline \multirow{3}{*}{ Plants } & \multicolumn{9}{|c|}{$\begin{array}{c}\text { TABLE-2 } \\
\text { PERCENTAGE (\%) YIELD OF SELECTED PLANTS USING METHANOL } \\
\text { SOLVENT FURTHER EXTRACTION INTO DIFFERENT SOLVENTS }\end{array}$} & \\
\hline & \multicolumn{2}{|c|}{ Methanol } & \multicolumn{2}{|c|}{$n$-Hexane } & \multicolumn{2}{|c|}{ Chloroform } & \multicolumn{2}{|c|}{ Ethyl acetate } & \multicolumn{2}{|c|}{$n$-Butanol } \\
\hline & Seed & W. Plant & Seed & W. Plant & Seed & W. Plant & Seed & W. Plant & Seed & W. Plant \\
\hline R. Communis & $52.2 \pm 0.4$ & $60 \pm 0.6$ & $20.8 \pm 0.4$ & $18.1 \pm 0.9$ & $15.2 \pm 0.7$ & $17.7 \pm 0.2$ & $8.2 \pm 0.8$ & $12.3 \pm 0.1$ & $6.4 \pm 0.6$ & $9.8 \pm 0.4$ \\
\hline D. innoxia & $56 \pm 0.7$ & $66 \pm 0.1$ & $16.2 \pm 0.2$ & $23.6 \pm 0.3$ & $18.7 \pm 0.6$ & $18.6 \pm 0.3$ & $11.2 \pm 0.2$ & $10.9 \pm 0.5$ & $5.7 \pm 0.4$ & $9.7 \pm 0.1$ \\
\hline C. tiglium & $51 \pm 0.2$ & $47 \pm 0.5$ & $18.1 \pm 0.8$ & $19.6 \pm 0.8$ & $14.9 \pm 0.5$ & $16.4 \pm 0.1$ & $9.7 \pm 0.7$ & $4.3 \pm 0.2$ & $6.5 \pm 0.9$ & $3.7 \pm 0.3$ \\
\hline
\end{tabular}

Values were the average of triplicate samples $(n=3)$ Mean \pm S.D 


\begin{tabular}{|c|c|c|c|c|}
\hline \multicolumn{5}{|c|}{$\begin{array}{c}\text { TABLE-3 } \\
\text { PERCENTAGE YIELD OF MEDICINAL PLANT FROM } \\
\text { DIFFERENT PARTS ON THE BASIS OF } \\
\text { EXTRACTION METHODS }\end{array}$} \\
\hline \multirow{2}{*}{ Plant name } & \multirow{2}{*}{ Plant Part } & \multicolumn{3}{|c|}{ Extraction method } \\
\hline & & Shaking & Sonication & Soxhlet \\
\hline \multirow{5}{*}{ R. communis } & Seeds & $60.72 \pm .3$ & $52.8 \pm .5$ & $27.09 \pm .6$ \\
\hline & Stems & $6.5 \pm .4$ & $4.4 \pm .1$ & $2.85 \pm .8$ \\
\hline & Leaves & $39.4 \pm .6$ & $18.4 \pm .6$ & $6.88 \pm .9$ \\
\hline & Fruits & $21.5 \pm .4$ & $16.2 \pm .1$ & $5.9 \pm .6$ \\
\hline & Roots & $4.84 \pm .3$ & $4.1 \pm .2$ & $2.4 \pm .4$ \\
\hline \multirow{5}{*}{ D. innoxia } & Seeds & $13.4 \pm .9$ & $9.65 \pm .8$ & $16.07 \pm .8$ \\
\hline & Stems & $13.9 \pm .8$ & $11.65 \pm .3$ & $2.04 \pm .9$ \\
\hline & Leaves & $19.4 \pm .3$ & $18.3 \pm .4$ & $5.92 \pm .3$ \\
\hline & Fruits & $15.5 \pm .4$ & $12.6 \pm .6$ & $8.9 \pm .7$ \\
\hline & Roots & $21.5 \pm .1$ & $18.85 \pm .9$ & $5.7 \pm .5$ \\
\hline \multirow{5}{*}{ C. tiglium } & Seeds & $16.65 \pm .8$ & $33 \pm .8$ & $24.06 \pm .4$ \\
\hline & Stems & $8.4 \pm .5$ & $5.4 \pm .3$ & $1.97 \pm .7$ \\
\hline & Leaves & $17.6 \pm .4$ & $8.9 \pm .7$ & $3.5 \pm .8$ \\
\hline & Fruits & $14.45 \pm .8$ & $9.5 \pm .4$ & $4.6 \pm .9$ \\
\hline & Roots & $6.4 \pm .2$ & $3.6 \pm .5$ & $2.3 \pm .2$ \\
\hline
\end{tabular}

The values were the average of triplicate samples $(n=3)$ Mean \pm S.D

\begin{tabular}{lcccccc}
\multicolumn{7}{c}{ TABLE-4 } \\
\multicolumn{7}{c}{ PROXIMATE COMPOSITION OF } \\
\hline \multirow{2}{*}{ Sample communis, D. innoxia and C. tiglium } \\
\hline $\begin{array}{c}\text { Moisture } \\
(\%)\end{array}$ & Carbohydrate & Ash & Fat & Protein & Energy \\
& $(\%)$ & $(\%)$ & $(\%)$ & $(\%)$ & $($ Kcal $)$ \\
\hline R. communis & 11.2 & 49.43 & 26.4 & 2 & 10.973 & 241.86 \\
D. innoxia & 12 & 36.62 & 14 & 25.7 & 11.71 & 200.25 \\
C. tiglium & 12.8 & 63.53 & 16.2 & 2 & 5.5 & 276.26 \\
\hline
\end{tabular}

$5.5 \%$ in $C$. tiglium to $11.7 \%$ in D. innoxia, while the crude protein of the R. communis was found to be $10.9 \%$. According to the National Research Council of United States, crude protein less than $20 \%$ indicates low protein content. These crude protein results are however comparable with the result of some tropical plant seeds reported by Riaz et al. ${ }^{23}$ and Rizwan et al. $^{24}$. They reported that Diospyno mespiliformis and Entandrophrgma angolense had crude protein contents of 3.46 and $12.34 \%$, respectively. The moisture contents which represents the amount of water in the plant in free and bound form also varied among plants, $R$. communis showed lowest (11.2\%) moisture content, whereas $C$. tiglium had the highest $(12.8 \%)$ and the moisture content in D. innoxia was recorded to be $12 \%$. According to US NRC (1993), moisture content of 5-20\% are declared to be enough high and the result of present investigation are also comparable with for Gliricidia sepium (6.77\%), Albizu zygia (7.8\%), Doneillia ogea $(9.86 \%)$ and D. mespiliformis $(8.99 \%)^{12}$. However, these results were found to different as reported for Lophira lanceolata seed $(2.78 \%)$ by Lohlum et al. ${ }^{26}$. This difference might be due to the variation and difference in agro-climatic conditions and plant species.

The crude lipid contents were recorded similar in both C. tiglium and $R$. communis ( $2 \%$ ), whereas D. innoxia showed lipid contents significantly higher as compared to $C$. tiglium and $R$. communis which were found up to $25.7 \%$. Results of the lipid contents of present investigation were in line with Oseni et al. ${ }^{27}$ who studied the lipid contents of $D$. stramonium $L$. Total ash was highest in $R$. communis $(26.4 \%$ ), whereas, it was lowest in the D. innoxia (14\%) and C. tiglium showed ash contents $16.2 \%$. Ayuba et al..$^{12}$ recorded total ash contents in different parts of D. innoxia and found the ash content ranged from $16-25 \%$. In case of energy values, significantly high calories were recorded in plants under study which were $276.26,241.86$ and $200.25 \mathrm{Kcal}$ for C. tiglium, R. communis and $D$. innoxia, respectively. The carbohydrate contents in $C$. tiglium, $R$. communis and D. innoxia were recorded to be $63.53,49.43$ and $36.62 \%$, respectively.

Phytochemical components: $R$. communis, $D$. innoxia and C. tiglium different parts and whole plant were tested for phytochemical constituents both qualitatively and quantitatively. Different solvents and extraction methods were compared. The qualitative analysis for phytochemical constituents of medicinal plants are shown in Table-5. Results showed that alkaloids, flavonoids, saponin, steroid, phlobatannin, terpenoid, tannins and cardiac glycoside content were present in extracts. The extracts from different plant parts were also studied for phytochemicals. On the basis of qualitative analysis, phlobatannins were not detected except leaves of $C$. tiglium, while

TABLE-5

PHYTOCHEMICALS CONSTITUENTS QUALITATIVE ANALYSIS OF R. communis, D. innoxia AND C. tiglium

\begin{tabular}{|c|c|c|c|c|c|c|c|c|}
\hline Parts of plant & Alkaliods & Tannins & Saponins & Steriods & Phlobatannins & Flavonoids & Terpenoids & Cardiac glycosides \\
\hline \multicolumn{9}{|c|}{$R$. communis } \\
\hline Seeds & $+\mathrm{ve}$ & + ve & + ve & -ve & $-\mathrm{ve}$ & -ve & - ve & -ve \\
\hline Stems & +ve & -ve & -ve & -ve & -ve & + ve & + ve & -ve \\
\hline Leaves & +ve & $+\mathrm{ve}$ & + ve & + ve & -ve & + ve & -ve & - ve \\
\hline Fruits & + ve & + ve & $+\mathrm{ve}$ & -ve & -ve & +ve & -ve & -ve \\
\hline Roots & -ve & -ve & -ve & +ve & -ve & -ve & +ve & +ve \\
\hline \multicolumn{9}{|c|}{ D. innoxia } \\
\hline Seeds & + ve & $+\mathrm{ve}$ & +ve & -ve & -ve & -ve & -ve & - ve \\
\hline Stems & + ve & -ve & -ve & -ve & -ve & +ve & +ve & -ve \\
\hline Leaves & $+\mathrm{ve}$ & + ve & + ve & $+v e$ & -ve & + ve & -ve & -ve \\
\hline Fruits & +ve & +ve & +ve & -ve & -ve & +ve & -ve & -ve \\
\hline Roots & -ve & -ve & -ve & + ve & -ve & -ve & $+\mathrm{ve}$ & $+v e$ \\
\hline \multicolumn{9}{|c|}{ C. tiglium } \\
\hline Seeds & $+\mathrm{ve}$ & $+\mathrm{ve}$ & + ve & -ve & -ve & -ve & + ve & $+\mathrm{ve}$ \\
\hline Leaves & +ve & +ve & $+\mathrm{ve}$ & +ve & +ve & +ve & - & -ve \\
\hline Fruits & $+v e$ & + ve & $+v e$ & - & -ve & +ve & - & - \\
\hline Roots & - & - & - & +ve & -ve & - & +ve & $+\mathrm{ve}$ \\
\hline
\end{tabular}


cardiac glycosides were detected only in roots of $R$. communis and $D$. innoxia. The $C$. tiglium roots and seeds also showed the presence of cardiac glycosides.

After qualitative analysis of phytochemical constituents, the alkaloids, falvonoids and saponins were measured quantitatively since these constituents are more common and important versus others and results are shown in Table-6. Alkaloids are naturally occurring chemical compounds contain more than 12000 cyclic nitrogenous compounds and found subsequently more than $20 \%$ in global fauna ${ }^{28}$. Flavonoids are chemical species found naturally as a phytochemical in plant species having high potential of retarding the in vitro oxidation of lipoproteins ${ }^{29}$. Flavonoids are found to building an important role in pharmacology for developing antiinflammatory, antiallergic and antimicrobial medicines ${ }^{30}$. Saponins are one of class of organic compounds secondary metabolites and found in abundance in plant species. More specifically, they are amphipathic glycosides in terms of phenomenology and produce hydrophilic glycosides moieties when combined with lipophilic triterpene derivative ${ }^{28}$. The alkaloid, flavonoids and saponis in $R$. communis seeds were recorded to be $10.4 \pm 0.4$, $8.3 \pm 0.7$ and $0.4 \pm 0.2 \%$, respectively. In stem, alkaloid content was recorded to be $1.8 \pm 0.2 \%$ and that of saponin $0.8 \pm$ $0.9 \%$. Overall, leaves showed high alkaloid contents, flavonoids and saponins which were $5.6 \pm 0.8,28 \pm 0.2$ and $2.6 \pm$ $0.4 \%$, respectively in $R$. communis. The $R$. communis fruits also showed good quantity of alkaloid $(7.8 \pm 0.5 \%)$, flavonoid $(19 \pm 0.8 \%)$ and saponin $(2 \pm 0.4 \%)$. In roots of $R$. communis, alkaloid, flavonoids and saponis were not detected. In $D$. innoxia, the alkaloids, flavonoids and saponins were recorded in the range of 0.6-9.4, 3.3-21 and 1-2\%, respectively, whereas C. tiglium showed 9.4, 18 and $1 \%$ alkaloids, flavonoids and saponin, respectively. The $D$. innoxia plant parts showed alkaloid content as: leaves $>$ fruits $>$ stems $=$ roots $>$ seeds and $R$. communis as: seeds $>$ fruits $>$ leaves $>$ stems. $C$. tiglium ranking is seeds $>$ leaves $>$ stems. The flavonoid content was recorded in all selected medicinal plant species i.e., stems, seeds, leaves and fruits. However, plants and plants parts showed varied quantity of alkaloid, flavonoid and saponin. Overall, maximum flavonoid content ( $28 \%$ ) was observed in $R$. communis,

\begin{tabular}{|c|c|c|c|c|}
\hline \multicolumn{5}{|c|}{$\begin{array}{c}\text { TABLE-6 } \\
\text { PHYTOCHEMICAL CONSTITUENT } \\
\text { QUANTITATIVE ANALYSIS OF Riccinus communis }\end{array}$} \\
\hline Plants & $\begin{array}{l}\text { Plant } \\
\text { parts }\end{array}$ & Alkaloids (\%) & Flavonoids (\%) & Saponins (\%) \\
\hline \multirow{5}{*}{ R. communis } & Seeds & $10.6 \pm 0.4$ & $8.3 \pm .7$ & $0.4 \pm 0.2$ \\
\hline & Stems & $1.8 \pm 0.2$ & - & $0.8 \pm 0.9$ \\
\hline & Leaves & $5.6 \pm 0.8$ & $28 \pm 0.2$ & $2.6 \pm 0.4$ \\
\hline & Fruits & $7.8 \pm 0.5$ & $19 \pm 0.8$ & $2.0 \pm 0.4$ \\
\hline & Roots & - & - & - \\
\hline \multirow{5}{*}{ D. innoxia } & Seeds & $0.6 \pm 0.3$ & $3.3 \pm 0.7$ & $1.0 \pm 0.4$ \\
\hline & Stems & $1.6 \pm 0.5$ & $18.3 \pm 0.2$ & $1.0 \pm 0.3$ \\
\hline & Leaves & $9.4 \pm 0.8$ & $4.6 \pm 0.5$ & 0.0 \\
\hline & Fruits & $3.2 \pm 0.2$ & $14.6 \pm 0.7$ & $2.4 \pm 0.3$ \\
\hline & Roots & $1.6 \pm 0.7$ & $21 \pm 0.1$ & 0.0 \\
\hline \multirow{5}{*}{ C. tiglium } & Seeds & $0.6 \pm 0.4$ & $3.3 \pm 0.7$ & $1.0 \pm 0.3$ \\
\hline & Stems & $1.6 \pm 0.2$ & $18.3 \pm 0.4$ & $1.0 \pm 0.7$ \\
\hline & Leaves & $9.4 \pm 0.7$ & $4.6 \pm 0.1$ & - \\
\hline & Fruits & $3.2 \pm 0.9$ & $14.6 \pm 0.3$ & $2.4 \pm 0.5$ \\
\hline & Roots & $1.6 \pm 0.2$ & $21 \pm 0.6$ & - \\
\hline
\end{tabular}

while minimum was recorded in D. innoxia seed (3.3\%). Other than chemical test, the presence of phytochemicals in plant extracts was also confirmed by performing the FTIR study. The FTIR spectrum of saponins can be seen in Fig. 1 (FTIR data of flavonoids and alkaloids is not provided). Saponins showed characteristic peaks of hydroxyl group $(-\mathrm{OH})$ ranging from 3372 to $3334 \mathrm{~cm}^{-1}$; C-H ranging from 2978 to $2926 \mathrm{~cm}^{-1}$; $\mathrm{C}=\mathrm{C}$ absorbance ranging from 1659 to $1640 \mathrm{~cm}^{-1} ; \mathrm{C}=\mathrm{O}$ ranging from 1742 to $1715 \mathrm{~cm}^{-1}$. The absorption band in IR spectrum appeared in the range from 1058 to $1036 \mathrm{~cm}^{-1}$ is assigned to $\mathrm{C}-\mathrm{O}$ stretching vibration. The detected peaks for saponins are in accordance with reported literature ${ }^{31}$.

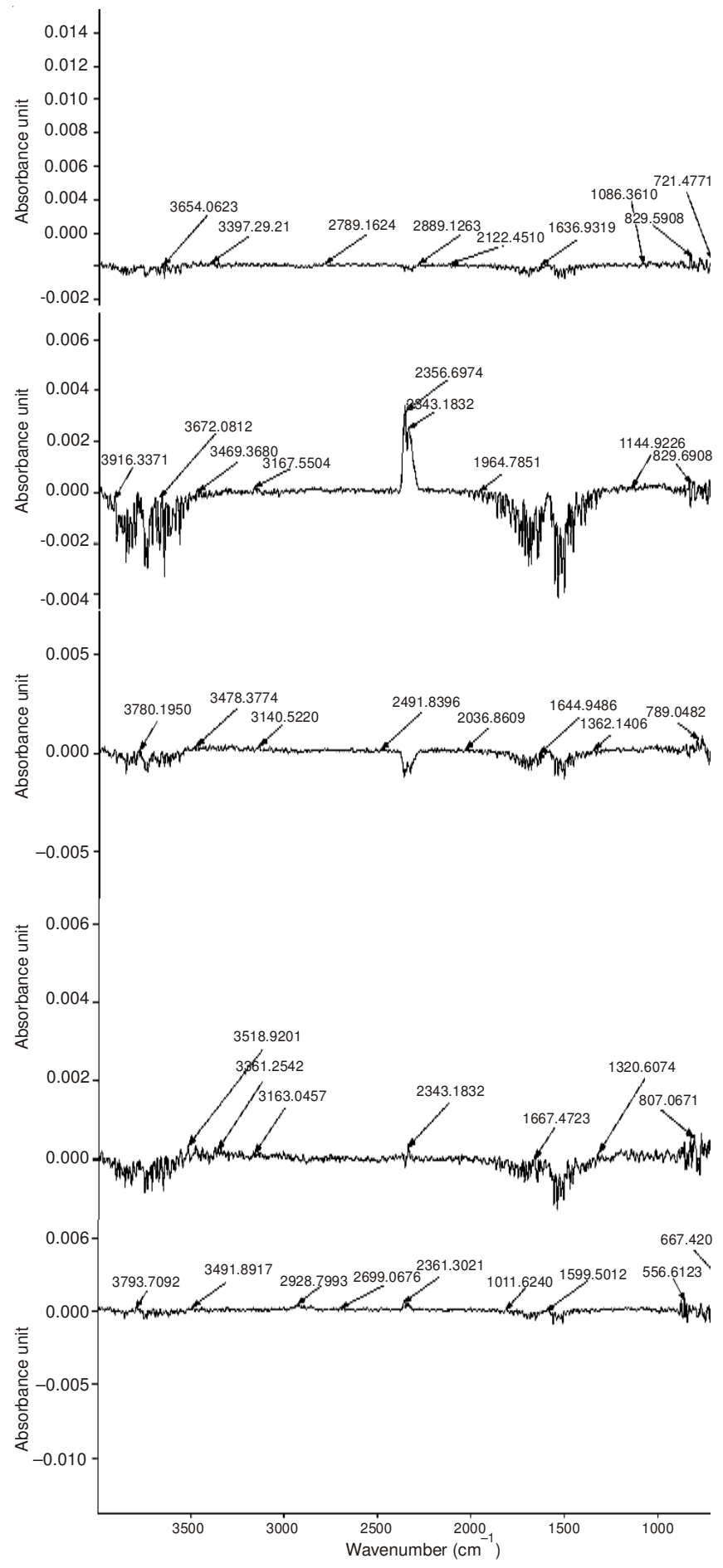

Fig. 1. Fourier transform infra red spectra of saponins 


\section{Conclusion}

Phytochemical screening of the plant extracts revealed the presence of alkaloids, tannins, saponins, steroids, phlobatannins, flavonoids, terpenoids and cardiac glycosides. Plants and plant parts showed varying level of phytochemical and in considerable higher quantity. Among solvent methanol showed good activity for the extraction of bioactive compounds and shaking method was found better as compared to sonication and soxhlet. The phytochemicals tested are known to exhibit medicinal activity and physiological activity and these component are also responsible for antimicrobial and antioxidant activities. The presence of biologically active compound in the $R$. communis, $C$. tiglium and $D$. innoxia extracts highlighted medicinal importance of these medicinal plants and may be potential sources of useful drugs. In future study, the antimicrobial, antioxidant, cytotoxic and mutagenic activities of these medicinal plants will be evaluated.

\section{REFERENCES}

1. A. Akrout, H. Mighri, M. Krid, F. Thabet, H. Turki and M. Neffati, Int. J. life Sci. Pharm. Res., 2, 1 (2012).

2. V.M. Kensa and S.S. Yasmin, Plant Sci. Feed, 1, 167 (2011).

3. M. Gulfraz, S. Mehmood, A. Ahmad, N. Fatima, Z. Praveen and E.M. Williamson, Phytother. Res., 22, 1208 (2008).

4. S.B. Elhardallo, Res. J. Med. Plants, 5, 201 (2011).

5. J. Asghari, B. Ondruschka and M. Mazaheritehrani, J. Med. Plants Res., 5, 495 (2011).

6. N.K. Kaushik, A. Bagavan, A. Rahuman, D. Mohanakrishnan, C. Kamaraj, G. Elango, A. Zahir and D. Sahal, Exp. Parasitol., 134, 26 (2013).

7. Z.K. Shinwari, J. Med. Plants Res., 4, 161 (2010).

8. M. Ibrar, F. Hussain and A. Sultan, Pak. J. Bot., 39, 329 (2007).

9. P. Tiwari, B. Kumar, M. Kaur, G. Kaur and H. Kaur, Int. Pharm. Sci., 1, 98 (2011)

10. M. Tomaniova, J. Hajslova, J. Pavelka Jr., V. Kocourek, K. Holadova and I. Klimova, J. Chromatogr. A, 827, 21 (1998).
11. E. Chukeatirote and T. Saisavoey, Int. J. Sci. Technol., 3, 212 (2009).

12. V.O. Ayuba, T.O. Ojobe and S.A. Ayuba, J. Med. Plants Res., 5, 2952 (2011).

13. P. Pushp, N. Sharma, G.S. Joseph and R.P. Singh, J. Food Sci. Technol., 50, 567 (2013).

14. L. Barros, L. Cabrita, M.V. Boas, A.M. Carvalho and I.C.F.R. Ferreira, Food Chem., 127, 1600 (2011).

15. E. Menghani, K. Bhatnagar, P. Saraswat and M. Soni, Int. J. Pharma. Res. Develop., 4, 113 (2012).

16. C.S. Misra, K. Pratyush, M.S.L. Dev, J. James, A.K.T. Veettil and V. Thankamani, Int. J. Resour. Phytochem. Pharmacol., 1, 77 (2011).

17. S.K. Biswas, A. Chowdhury, J. Das, U.K. Karmakar and M.C. Shill, Int. J. Pharm. Sci. Res., 2, 2605 (2011).

18. G. Uddin, A. Rauf, T. Rehman and M. Qaisar, Middle-East J. Sci. Res., 7, 707 (2011).

19. N. Savithramma, M.L. Rao and D. Suhrulatha, Middle-East J. Sci. Res., 8, 579 (2011).

20. R. Sutharsingh, S. Kavimani, B. Jayakar, M. Uvarani and A. Thangathirupathi, Int. J. Pharm. Stud. Res., 2, 52 (2011).

21. A.M. Khan, R.A. Qureshi, F. Ullah, S.A. Gilani, A. Nosheen, S. Sahreen, M.K. Laghari, M.Y. Laghari, S. Rehman, I. Hussain and W. Murad, J. Med. Plants Res., 5, 6017 (2011).

22. Y. Vaghasiya, R. Dave and S. Chanda, Res. J. Med. Plants, 5, 567 (2011).

23. M. Riaz, N. Rasool, I. Bukhari, M. Shahid, M. Zubair, K. Rizwan and U. Rashid, Molecules, 17, 14275 (2012).

24. K. Rizwan, M. Zubair, N. Rasool, M. Riaz, M. Zia-Ul-Haq and V. de Feo, Int. J. Mol. Sci., 13, 6440 (2012).

25. H. Zhao, J. Dong, J. Lu, J. Chen, Y. Li, L. Shan, Y. Lin, W. Fan and G. Gu, J. Agric. Food Chem., 54, 7277 (2006).

26. S.A. Lohlum, African J. Food Agric. Nutr. Develop., 10, 15 (2010).

27. O.A. Oseni, C.O. Olarinoye and I.A. Amoo, African J. Food Sci., 5, 40 (2011).

28. B.P. Gaire, R. Lamichhane, C.B. Sunar, A. Shilpakar, S. Neupane and S. Panta, Pharm. J., 3, 1 (2011).

29. S. Kiruba, M. Mahesh, Z.M. Paul and S. Jeeva, Asian Pacific J. Trop. Biomed., 1, S129 (2011).

30. M. Kumar, M. Chandel, M. Kumar and S. Kaur, Phytopharmacol., 1, 177 (2011)

31. S. Kirmizigul and H. Anil, Turk J. Chem., 26, 947 (2002). 